\title{
Technè
}

La science au service de l'histoire de l'art et de la préservation des biens culturels

45 | 2017

Bronzes grecs et romains : études récentes sur la statuaire antique

\section{The Bronze Athlete from Ephesos: Archaeological Background and Aspects of Conservation}

L'athlète en bronze d'Éphèse, contexte archéologique et éléments de restauration

\author{
Georg A. Plattner
}

\section{(2) OpenEdition \\ 1 Journals}

Electronic version

URL: http://journals.openedition.org/techne/1255

DOI: 10.4000/techne.1255

ISSN: 2534-5168

Publisher

C2RMF

\section{Printed version}

Date of publication: 1 May 2017

Number of pages: $34-45$

ISBN: 978-2-7118-6408-9

ISSN: 1254-7867

Electronic reference

Georg A. Plattner, «The Bronze Athlete from Ephesos: Archaeological Background and Aspects of Conservation », Technè [Online], 45 | 2017, Online since 19 December 2019, connection on 10 December 2020. URL : http://journals.openedition.org/techne/1255 ; DOI : https://doi.org/10.4000/ techne. 1255

\section{cc)}

La revue Technè. La science au service de l'histoire de l'art et de la préservation des biens culturels est mise à disposition selon les termes de la Licence Creative Commons Attribution - Pas d'Utilisation Commerciale - Pas de Modification 4.0 International. 


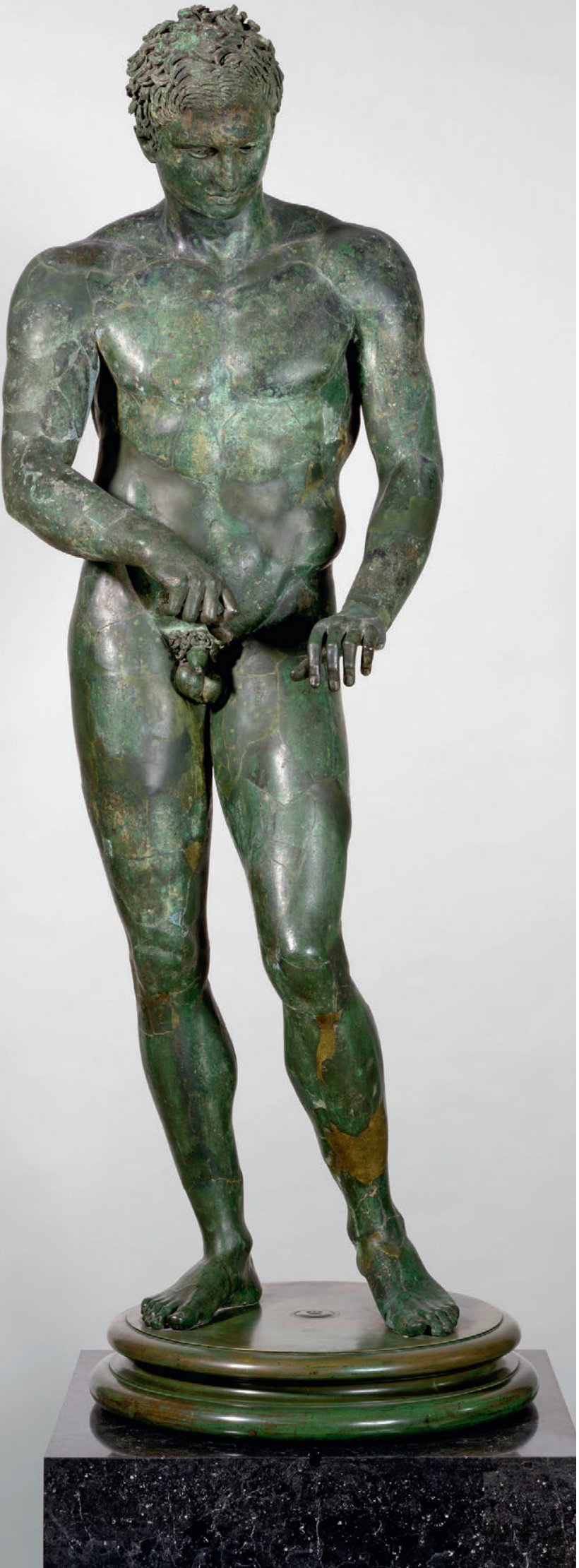

Fig. 1. Ephesian Athlete, bronze, H. 192 cm, second half of 1st cent. A.D., Kunsthistorisches Museum Vienna, Collection of Greek and Roman Antiquities, inv. no. VI 3168. (C) Kunsthistorisches Museum Vienna. 
Georg A. Plattner

\section{The Bronze Athlete from Ephesos: Archaeological Background and Aspects of Conservation}

L'athlète en bronze d'Éphèse, contexte archéologique et éléments de restauration

Abstract. The Athlete from Ephesos, a Roman imperial copy of a Greek statuary type from the 4th century B.C., was found at the very end of the 19th century, in the first years of the Austrian excavation in Ephesos, when research was concentrated on the major imperial monuments. In the palaestra of the Harbor Baths, the statue was set up in an aedicula and was destroyed when an earthquake caused the collapse of the hall roof.

Due to an agreement between the Ottoman Sultan Abdul Hamid II and the Austrian Emperor Franz Joseph I, the fragments could be taken to Vienna as a gift to the emperor's collections. In Vienna, Wilhelm Sturm was commissioned with the restoration and conservation of the statue in 1897. The recomposition of the athlete took as a model the marble athlete kept at the Uffizi, in Florence, once the similarity of the statuary type of the Apoxyomenos had been recognized.

The individual fragments were treated physically and chemically and were fixed on brass strings. Then groups of fragments were mounted onto iron bars in order to build the "back bone".

The entire statue was filled with cement in order to stabilize the structure and to close the gaps in the surface.

A reevaluation of the condition of the Ephesian statue in cooperation with the Conservation Science Department of the Kunsthistorisches Museum and the Antiquities Conservation Department of the J. Paul Getty Museum, Malibu, California has shown the surprisingly good condition of the more than 100 yearold reconstruction.

Keywords. Ephesos, Vienna, Apoxyomenos, bronze sculpture, conservation, excavation.
Résumé. La découverte de l'athlète d'Éphèse remonte aux premières années de fouilles autrichiennes à Éphèse, alors que les recherches se concentraient sur les principaux monuments impériaux. L'effondrement de la toiture, provoquée par un tremblement de terre, avait brisé la statue installée dans un édicule au sein de la palestre des thermes du port.

Un accord entre le sultan ottoman Abdul Hamid II et l'empereur d'Autriche François-Joseph $I^{\text {er }}$ permet de transporter les fragments à Vienne dans le cadre d'un don aux collections impériales. À Vienne, Wilhelm Sturm se voit confier la restauration de la statue. Il prend modèle sur la statue d'athlète conservée au musée des Offices, à Florence, en s'appuyant sur un rapprochement typologique.

Chacun des fragments fait l'objet d'un traitement physique et chimique, avant d'être fixé sur des cordes de laiton. Les groupes de fragments ainsi constitués sont montés sur des barres de fer afin de construire un squelette. Du ciment coulé dans les interstices consolide l'ensemble et comble les lacunes en surface.

Une réévaluation de l'état de la statue d'Éphèse, conduite par le laboratoire de conservation-restauration du Kunstorisches Museum de Vienne en collaboration avec le département de conservation-restauration des Antiquités du musée J. Paul Getty, Malibu, Californie, souligne la stabilité étonnante de la restauration effectuée voilà plus de cent ans.

Mots-clés. Éphèse, Vienne, apoxyomène, statues en bronze, restauration, fouilles.

\section{Austrian Excavations in Ephesos}

In the first years of the Austrian excavations in Ephesos, starting in 1895, the focus of the work was set on major public buildings as the Grand Theatre and the so called Harbour Baths, a spacious bath-gymnasium-complex from the late 1st century A.D. (fig. 2-3) ${ }^{1}$. Already in the second year, in 1896, the Austrian mission unearthed the palaestra of these baths, discovering a splendid marble hall with several sculptures and minor elements of architectural decoration ${ }^{2}$. Right in front of this marble hall in the south-west corner of the palaestra, 234 fragments of a life-size bronze sculpture were brought to light, a masterpiece of ancient art known since then as the Athlete or the "Schaber" from Ephesos (fig. 1) ${ }^{3}$.

Due to an Irade, an edict of Sultan Abdul Hamid II, some of the excavated finds could be chosen by the Austrian ambassador, Freiherr von Calice; these were sent to Vienna as a gift of the Sultan to the Austrian Emperor Franz Joseph I ${ }^{4}$. The Austrian Lloyd company brought the sculptures, architectural elements and small finds to Vienna in six transports

Dr. Georg A. Plattner, Kunsthistorisches Museum Wien, Collection of Greek and Roman Antiquities/Ephesos Museum, Vienna, Austria (georg.plattner@khm.at). 


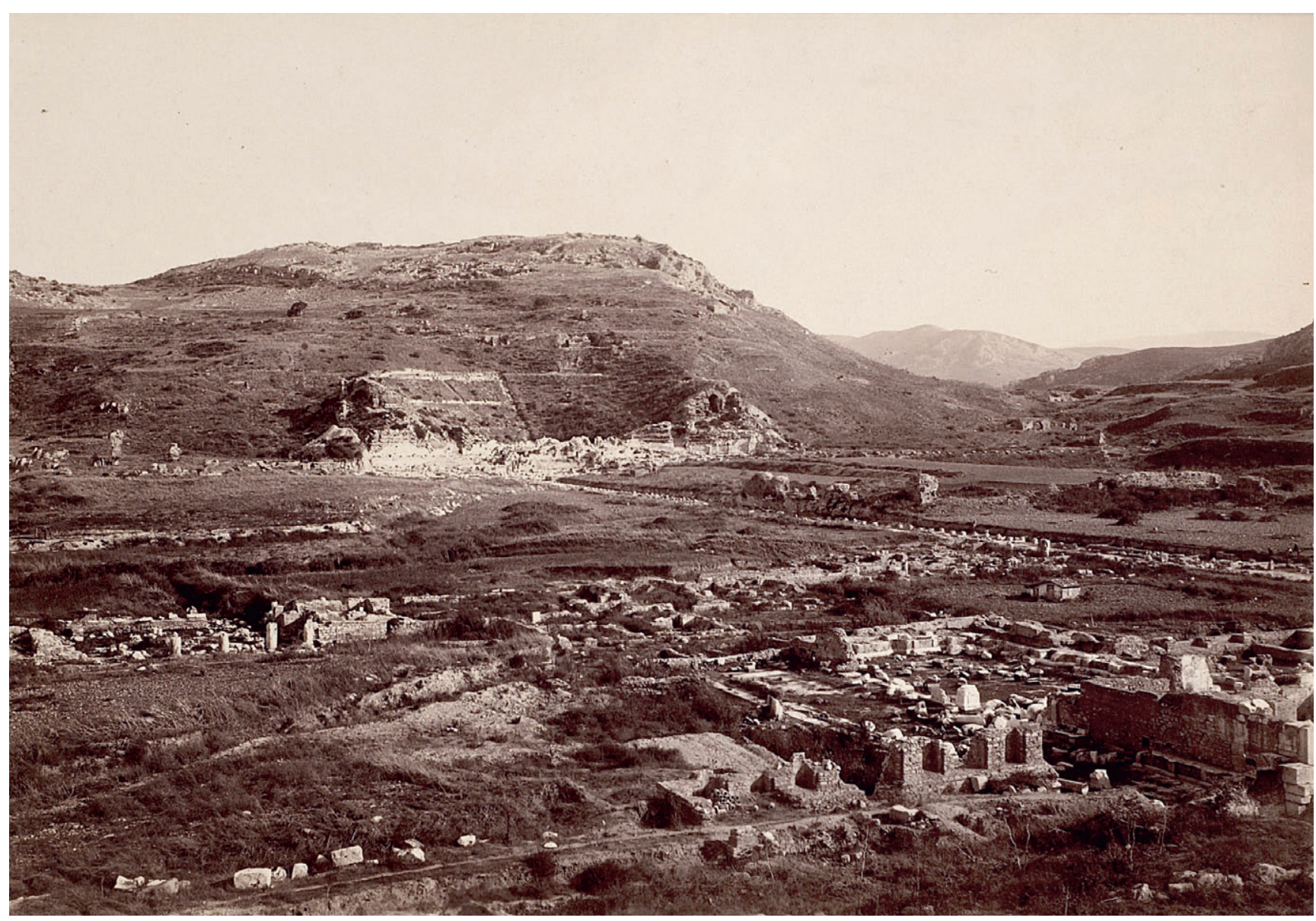

Fig. 2. Ephesos, Harbour Baths around 1900, seen from north-east, in the background the Great Theatre. (C) Austrian Archaeological Institute.

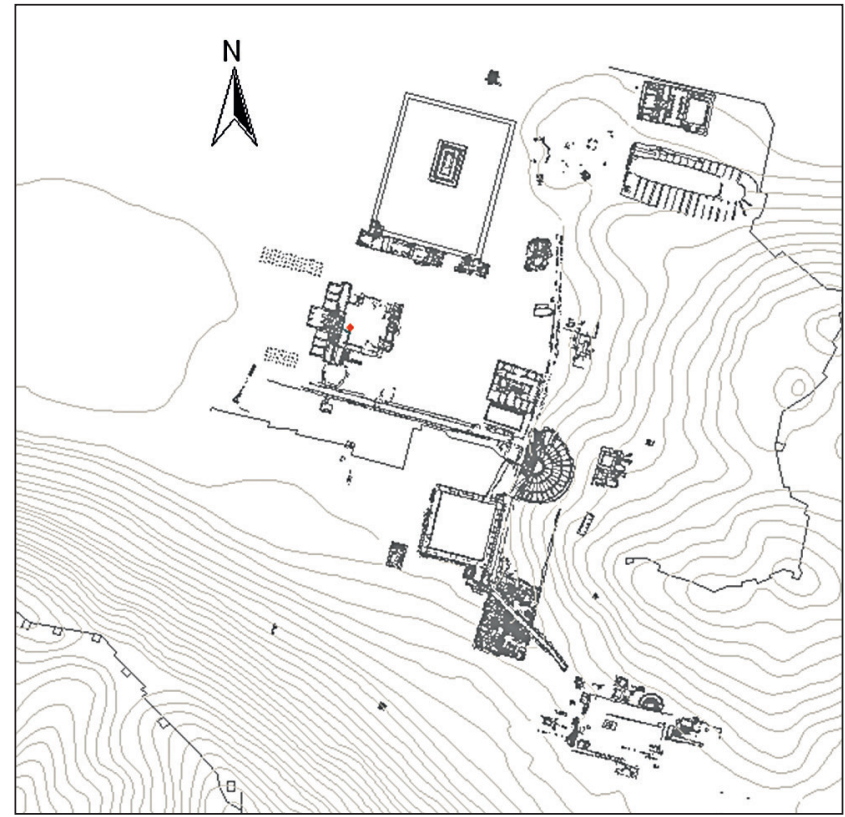

Fig. 3. Ephesos, overview plan, marked in red: find spot of the statue in the Harbour Baths. @ Austrian Archaeological Institute. until 1906. From 1907 onwards, a new law concerning the legal framework of preservation of antiquities, promoted by Osman Hamdi Bey, founder of the Istanbul Archaeological Museum, prohibited to take any archaeological heritage abroad. Today, most of the finds from Ephesos brought to Vienna are on display in the Ephesos Museum, which opened in 1978 in the former imperial palace of the Habsburg house in Vienna ${ }^{5}$.

\section{The bronze athlete and its early conservation}

As early as 1897, the fragments of the bronze athlete came to Vienna (fig. 4) ${ }^{6}$. The sculptor Wilhelm Sturm Jr. was commissioned to reconstruct the heavily damaged statue which he did in the first half of the year 1897. Later on, in 1901, he was appointed as conservator of the Antiquities Collection. Some passages of his report are cited in Benndorf's publication ${ }^{7}$, mentioning that several fragments had to undergo a serious treatment of heating and annealing, cleaning the surface with dilute hydrochloric acid and reshaping. The single fragments were arranged in groups 
and fixed to brass strings with screws; an invoice from Sturm kept in the Museum's archive mentions no less than 1800 brass screws used in the conservation project! The single groups were mounted onto a "skeleton" consisting of three square iron bars (fig. 5). To close the gaps in the surface caused by missing fragments and to stabilize the entire construction, Sturm decided to fill the hollow statue with a special cement up to the level of the neck ${ }^{8}$. The visible surface of the cement was then modelled and painted, and the original bronze surface treated with wax and partly, presumably, given an artificial patina.

Once restored, the statue went immediately on display in the first exhibition of "Fundstücke aus Ephesos" in the Theseus Temple in Vienna ${ }^{9}$. This temple is a reduced copy of the "Theseion" (Hephaistieion) in Athens, built by Pietro di Nobile in Vienna, in the years 1819-1823, to house the famous sculpture Theseus fighting the Minotaur from Antonio Canova. After transferring this sculpture to the main staircase of the

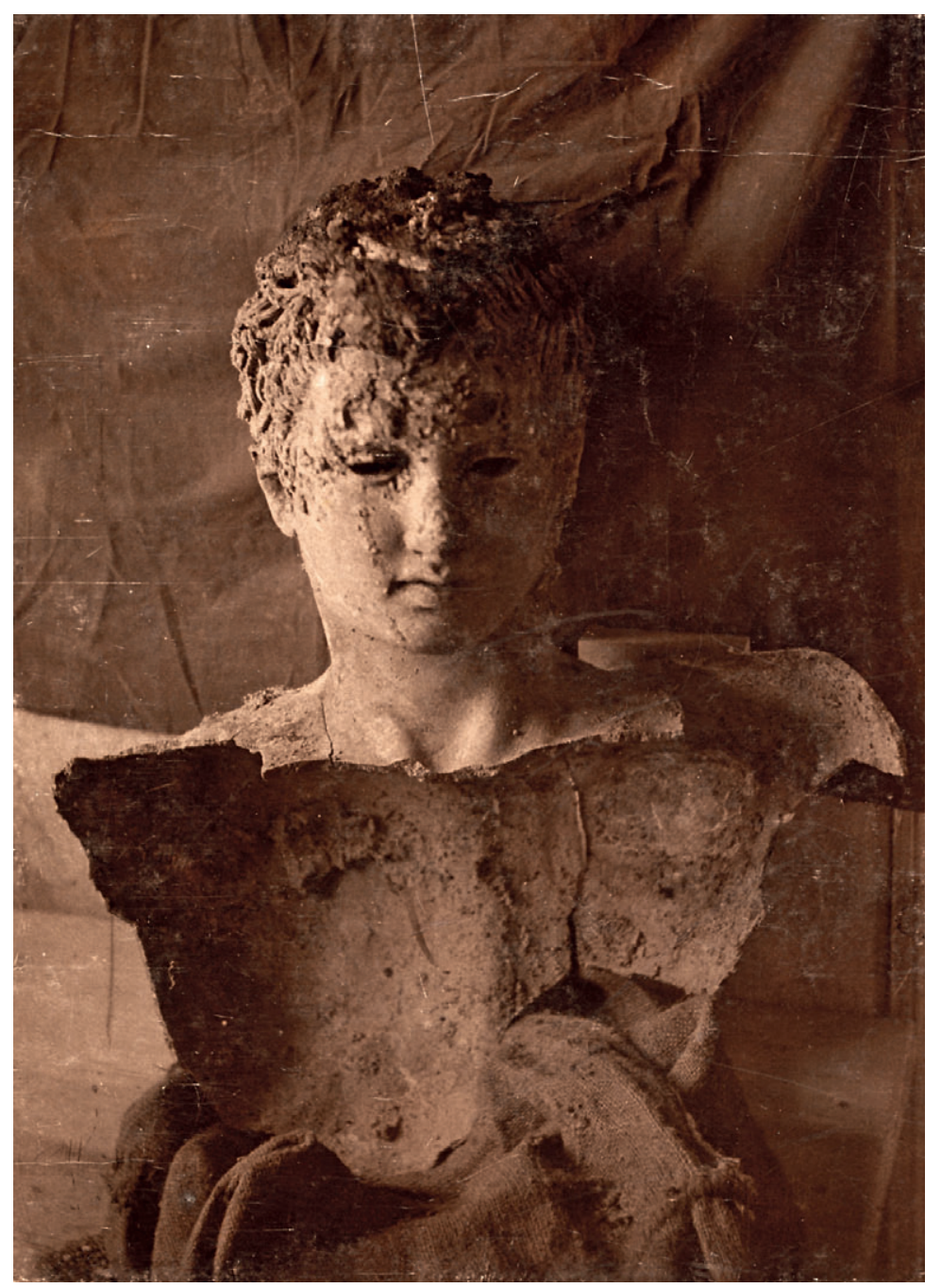

Fig. 4. The Athlete from Ephesos, head and shoulders before restoration. (c) Austrian Archaeological Institute.

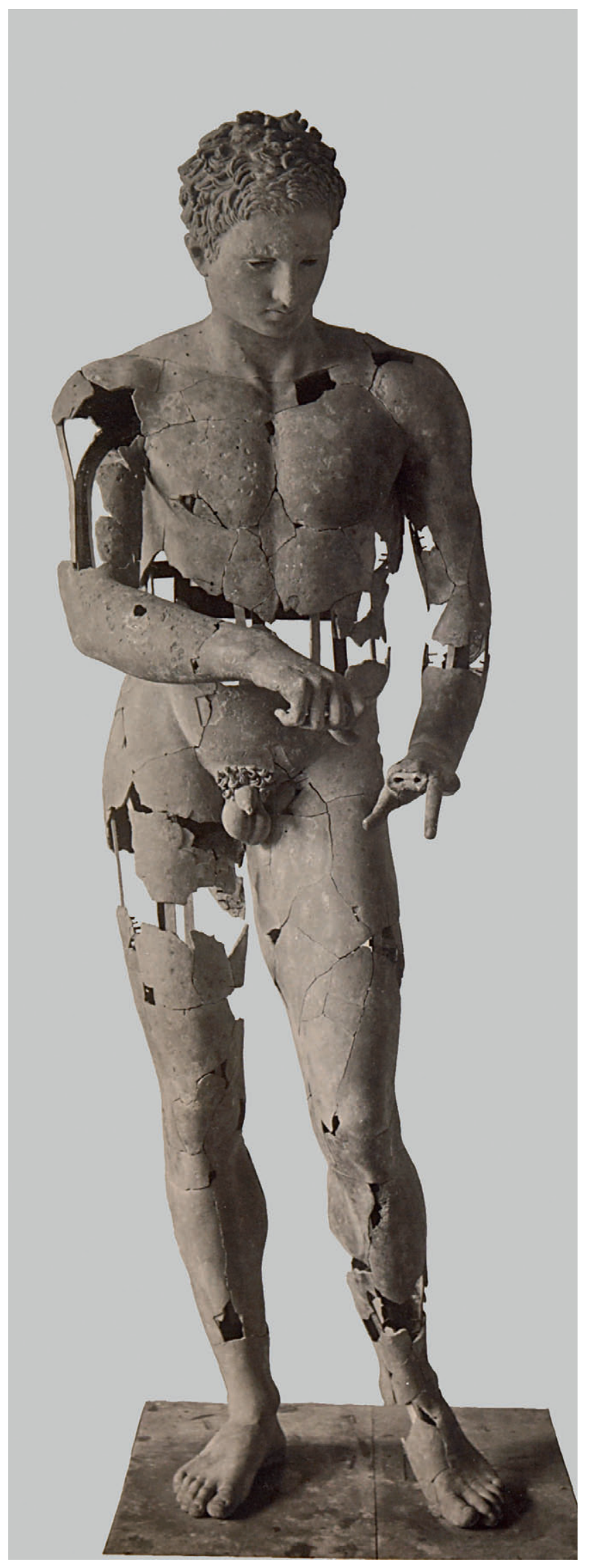

Fig. 5. Restoration of the statue by Wilhelm Sturm, 1897-1898. (c) Kunsthistorisches Museum Vienna. 


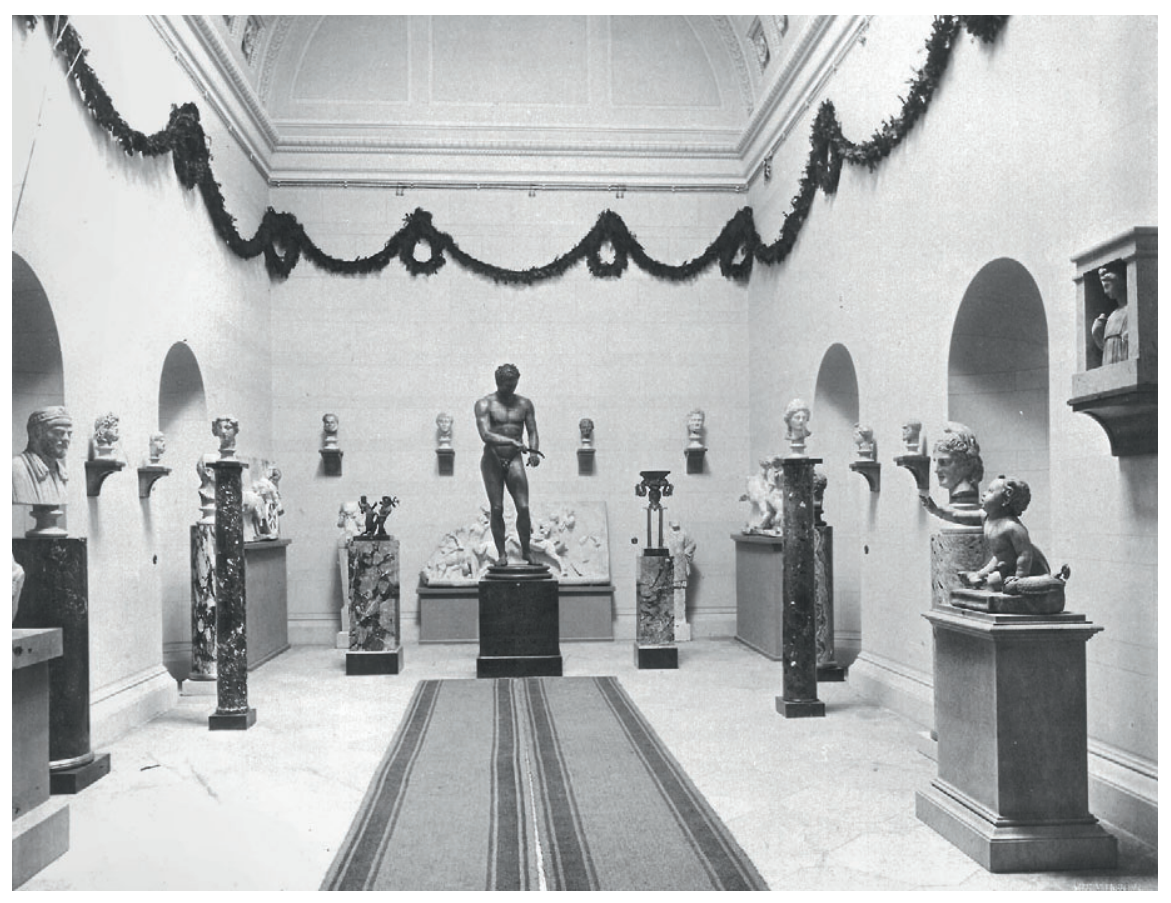

Fig. 6. Exhibition of finds from Ephesos in the "Theseus Tempel" in Vienna, 1901. (c) Kunsthistorisches Museum Vienna.
Kunsthistorisches Museum in the 1880ies, the temporary exhibition of the first finds from the new excavation abroad was on display in this temple and was received with high interest (fig. 6).

Very soon, it became clear that the humid environment in the temple, also caused by the spacious substructures, did severe harm to the bronze sculpture, which was removed only 10 years later. The composition of the cement probably accounted also for the problem as it contained a certain amount of hygroscopic chlorides.

The restoration technique and the approach to solve this complex three-dimensional puzzle gained international attention, as never before a task like this could be solved in a similar way. An official invitation from Athens reached Vienna, and Sturm went to Greece in 1901 to provide an expertise for the restoration of the Antikythera-sculptures ${ }^{10}$. However, as neither he wanted to stay for 6 months in Greece nor the sculptures could be taken abroad, he finally rejected the offer to work on this restoration in Athens.

\section{The athlete type Ephesos-Florence}

When reconstructing the Ephesian sculpture in 1897, one of the major tasks was to understand the statuary type and to find the position of every single fragment found in the excavation. Again, it must have been Otto Benndorf who provided the crucial knowledge, recognizing in the wellpreserved, mostly undamaged head of the statue and its position on the quite well preserved shoulder/back-zone, a statuary type already known through a famous specimen kept at the Uffizi in Florence ${ }^{11}$. Today, this athlete is on display in the Galleria degli Uffizi with modern arms added, holding a jug in his hands. A plaster cast of this sculpture was commissioned and Wilhelm Sturm used it as a model for reshaping the Ephesian Athlete $^{12}$.

Nevertheless, it was not possible to determine the precise arm and leg position as well as the position of every single fragment of the upper part of the body due to the size and deformation of the fragments or even their loss. In the end, some 10 fragments only could not be given a precise location.

The original composition of both the Ephesian and Florentine statues was early understood as that of an athlete; that became particularly clear because of the short hair, slicked to the forehead, appearing wet from sweating. The statuary type was understood as a work of the (late) classical period and was connected to the Apoxyomenai, the scrapers, named in ancient literature as a work of Polycleitus and his successors (see below). The concentrated gaze at the hands seemed to favour this interpretation, so the Ephesian Athlete was reconstructed cleaning his left arm or, more precisely, the back of his left hand with a stlengis, a scraper ${ }^{13}$.

Almost at the same time, around 1900, a smaller-thanlife-size sculpture found in 1896 in Frascati came to the Museum of Fine Arts in Boston ${ }^{14}$. The statue followed the same type as the athletes from Ephesos and Florence. The importance of this new find was that the hands were preserved. It became clear that the athlete was not scraping the back of his hand but rather cleaning the stlengis itself by using the thumb of his left hand ${ }^{15}$. Benndorf mentions this statue already in his publication of the Ephesian Athlete in $1906^{16}$. However, it was too late to incorporate these details in the restoration 


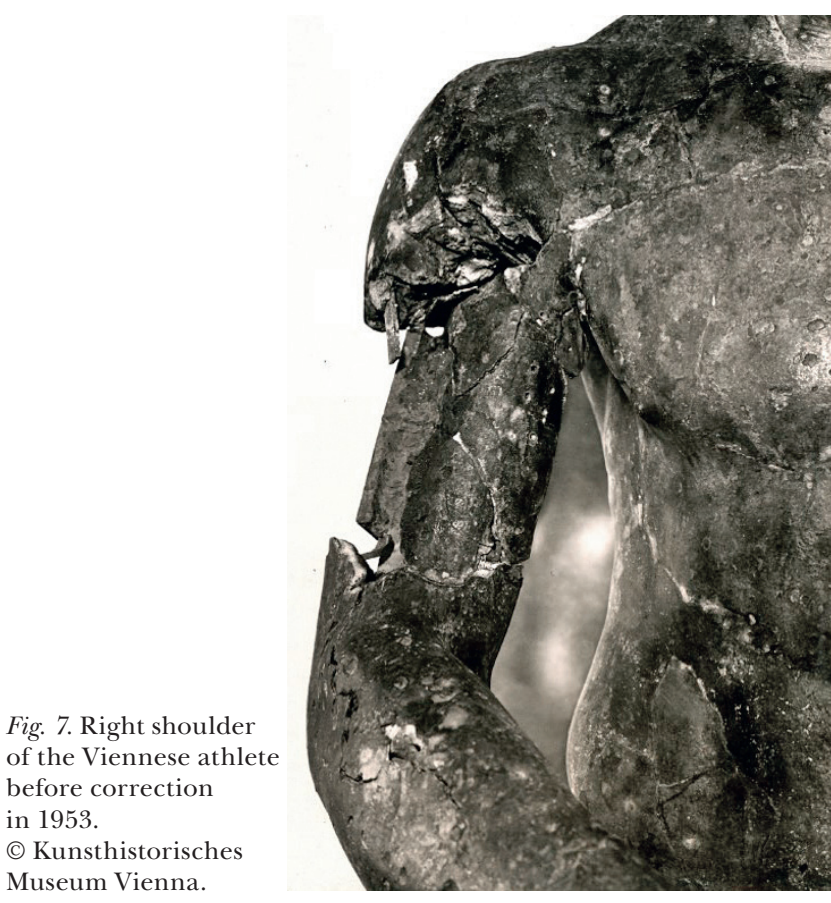

of the bronze statue from Ephesos. So the right arm remained mounted in a quite disturbing and - finally - wrong angle to the body (fig. 7).

Only half-a-century later, a major correction of the position of the right arm was undertaken. In 1948, the conservators took off the cement with which the right arm had been completed. In 1951, Karl Nieschlag was commissioned with the correction of the position, which required some serious interventions: the iron bar in the right arm could not be bent; it finally had to be cut off with a saw. With this correction, the fragments of the right shoulder and the upper right arm as well matched considerably better than before. Furthermore, the position of the arms corresponded much better with the turning of the head ${ }^{17}$.

During the course of the preparation of the installation of the Ephesos Museum in the "Neue Burg" in Vienna in the seventies, the athlete underwent another conservation treatment: Alois Heidel had to dismantle smaller parts of the statue; after reassembling them, he modeled the surface of some of the missing sections with synthetic resin. In that state, the Athlete has remained on display in the Ephesos Museum since 1978.

\section{The setting of the statue within the Ephesian Gymnasium}

To judge from the find spot of the Ephesian Athlete, it seemed that the statue was part of the sculptural program of the palaestra of the Harbour Baths ${ }^{18}$; statues of athletes - among which also a scraping athlete - are represented in a similar way, framed by columns and gables of a palaestra architecture, on several Campana reliefs, one of them from the first half of the 1st century A.D. in the Kunsthistorisches Museum in Vienna (fig. 8).

Caused by one of the numerous earthquakes that struck Ephesos, the halls of the palaestra collapsed, probably already in the 3rd century A.D. The statue was thrown off its base and fell forwards as the feet were found closest, the head furthest away from the pedestal ${ }^{19}$. The bronze fragments were buried by the wooden roof construction and the brick tiles of the hall ${ }^{20}$. Eventually, the south-west corner was the only section of the palaestra which remained untouched after this earthquake, whereas the main area of the palaestra was probably first looted and later on, presumably in the 5th century A.D., became part of the late antique town, as shown by the surprisingly well preserved wealthy living houses recently unearthed $^{21}$.

The south-west corner was not excavated, neither in antiquity nor in the earlier 19th century. Even John Turtle Wood, discoverer of the Artemision of Ephesos in 1869, working for the British Museum, refused to carry on excavations in this area, because the remnants of the roof and of the building structures obstructed the ongoing work ${ }^{22}$.

Otto Benndorf and his crew finally unearthed this southwest corner and found a solid masoned pedestal with bases and lower parts of pilasters, being part of a (mainly lost) aedicula, which once framed the statue (fig. 9). The socle and fragments of the pilasters remained in situ, the base was taken to Vienna. This base is profiled on three sides and bears an inscription on the front from which parts of 6 lines are readable (fig. 10 $)^{23}$. It mentions a Tiberius Claudius Frugianus as gymnasiarchos and a Tiberius Claudius [Aristion?] as grammateus, who is well-known as donator and builder in the late 1st century/beginning of 2 nd century A.D. We owe the knowledge of these names and the readability of the few fragments to four other bases of the same type also found in the palaestra, naming the same officials and dedications of further sculptures, which have not survived ${ }^{24}$.

Surprising and, in the end, misleading is the surface of the base: there are no holes nor even traces for or of fixing a sculpture on top of it. It is flat but not entirely even. Mentioning this fact, already Heberdey doubted that the base could have been used to bear a bronze sculpture, as the characteristic holes to fix the legs via lead poured into the feet were missing ${ }^{25}$.

In contrast, Frank Willer showed lately that, in the course of time, different techniques were used to fix bronze sculptures onto a base ${ }^{26}$. In Roman Imperial age, one of the methods consisted in fixing the statue to a metal panel or base rather than to the stone base itself; so in the end, the sculpture was "free standing" due to the enlarged platform ${ }^{27}$.

It is very uncommon to discover a bronze statue with its base, as in the case of the Ephesos athlete. Furthermore, statue and base are most probably from the same era. Taking into consideration the relatively short lifetime of this very corner of the Harbour Baths, this hypothesis seems likely: 
already in the 4th century A.D., the southern rooms adjacent to the palaestra were partly modified and reused in the new atrium thermarum Constantiniarum. It seems therefore that already in that time, the south-west corner of the palaestra was abandoned. So, the massive earthquakes which destroyed this part of the building might have been those of the later 3rd century A.D., recorded strikingly by the destruction of the famous Slope Houses of Ephesos ${ }^{28}$. Considering this, we envision a timespan of less than 200 years of "lifetime" for the base. Taking into consideration the technique and making of the bronze statue of the Athlete pointing to the late 1st/2nd century A.D., it is most likely that it is the very and the only statue ever positioned onto this base (fig. 11) ${ }^{29}$.

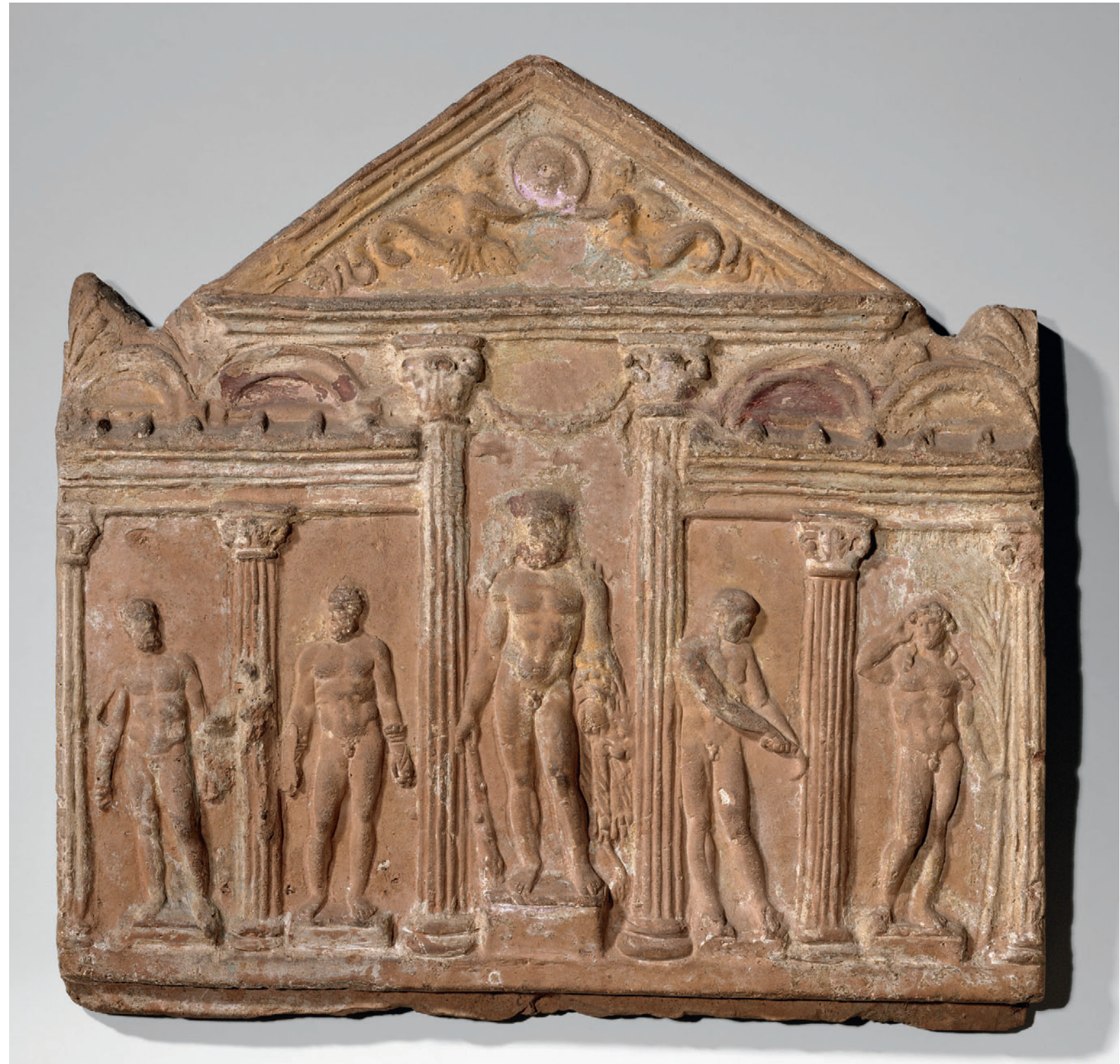

Fig. 8. Campana relief in Vienna showing statues in a palaestra, clay, H. $40 \mathrm{~cm}$, early 1st century A.D., Kunsthistorisches Museum Vienna, Collection of Greek and Roman Antiquities, inv. no. V 1895.

(C) Kunsthistorisches Museum Vienna. 


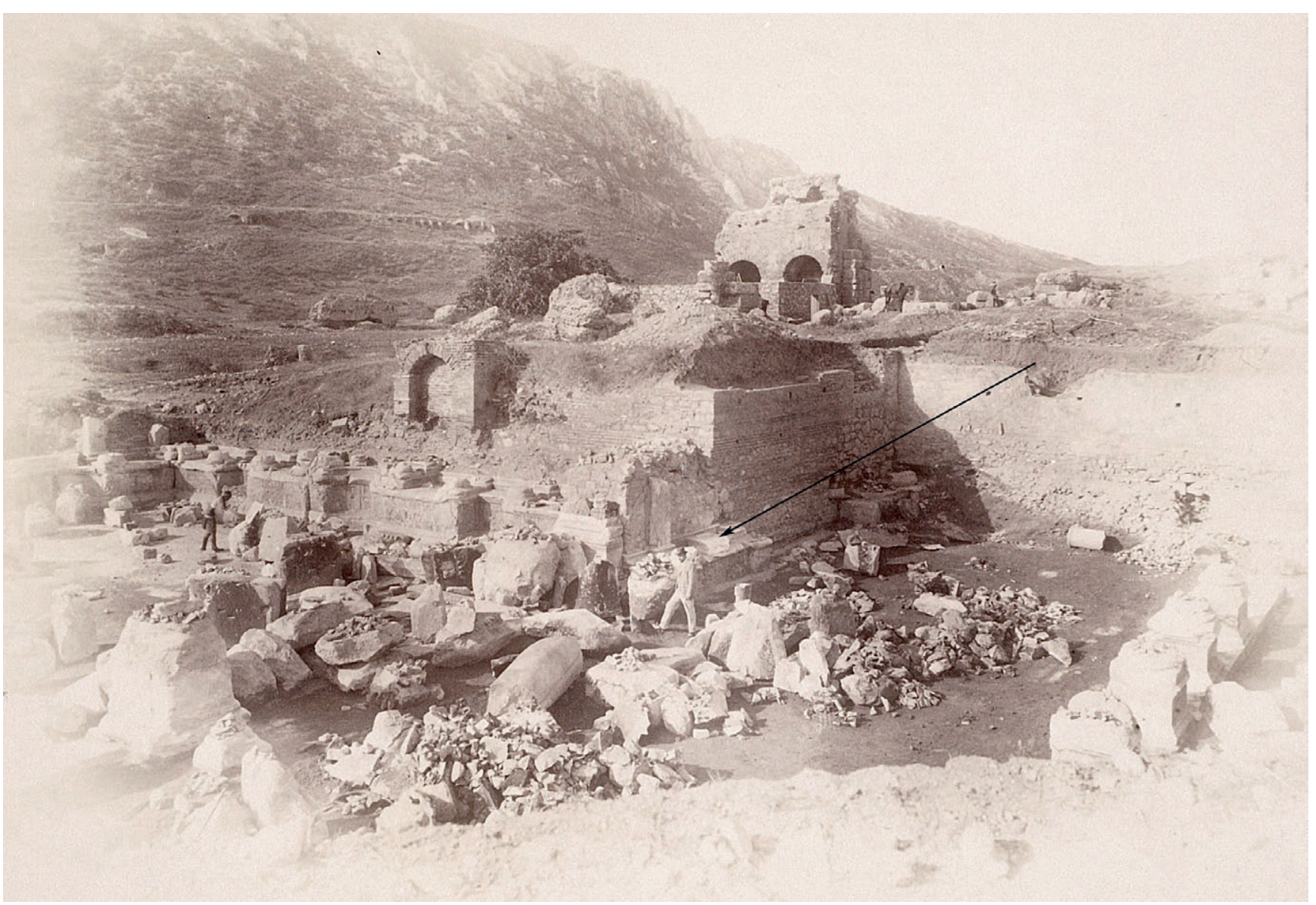

Fig. 9. Ephesos, Harbour Baths: excavations 1896-1897 in the southwest-corner of the palaestra. (c) Austrian Archaeological Institut (marked, the base of the athlete in situ).

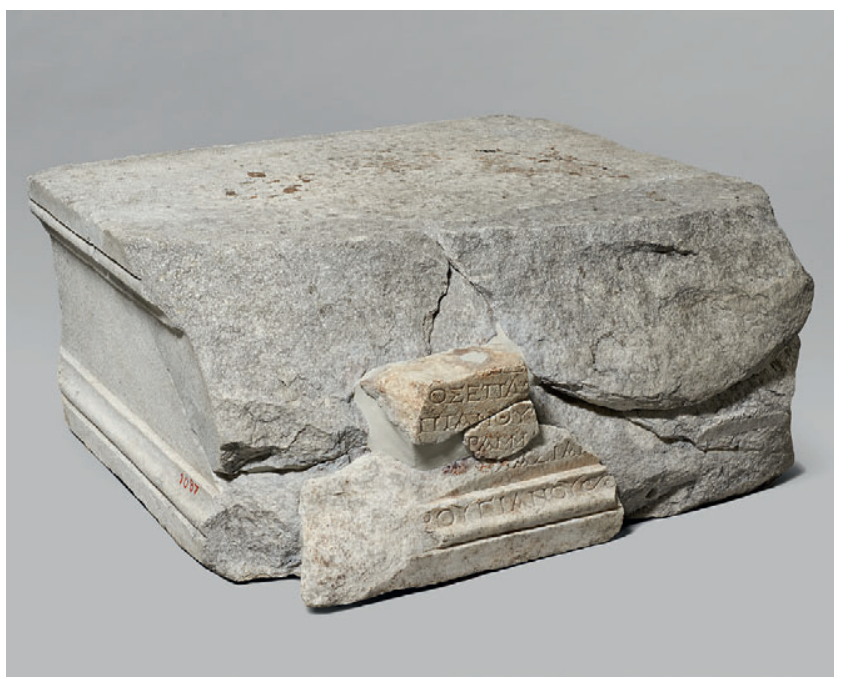

Fig. 10. Base found in the palaestra in Ephesos, marble, H. $30 \mathrm{~cm}$, late 1st century A.D., Kunsthistorisches Museum Vienna, Collection of Greek and Roman Antiquities, inv. no. III 1087. (C) Kunsthistorisches Museum Vienna.

\section{The archetype of the athlete}

After assuming or, perhaps, wishing to have unearthed a "Greek original" in the first moment, scholars soon agreed that the Ephesian Athlete was a Roman sculpture. However, until today, there is still a vivid discussion aiming at proving whether the statue is rather a copy of a Greek original or a Roman creation.

The statuary type of the Ephesian Athlete is known today through various statues/torsos ${ }^{30}$ and heads housed in different museums ${ }^{31}$. In small scale, two bronze statuettes follow this type $^{32}$, but the statuette at the Louvre differs slightly as the head raises up and the athlete does not look down to his hands. Depictions of the statuary type are furthermore preserved on Campana Reliefs ${ }^{33}$ as well as on gems ${ }^{34}$, even on a statuary base from the Acropolis of Athens ${ }^{35}$.

Apart from early theories suggesting to identify the Ephesian Athlete as one of the two Greek original scrapers created by Daidalos from Sikyon that Pliny mentioned ${ }^{36}$, it became soon quite clear that the statue had to be dated in the Roman era. Already Benndorf named it an "excellent copy from early Roman times" ${ }^{\prime 3}$. The various authors differ widely in dating the original work, the range goes from the 4th century B.C. to the end of the 1st century A.D.

Karin Moser von Filseck claims the Ephesian Athlete to be the link between Polykleitos and Lysippos ${ }^{38}$, while Dorothea 


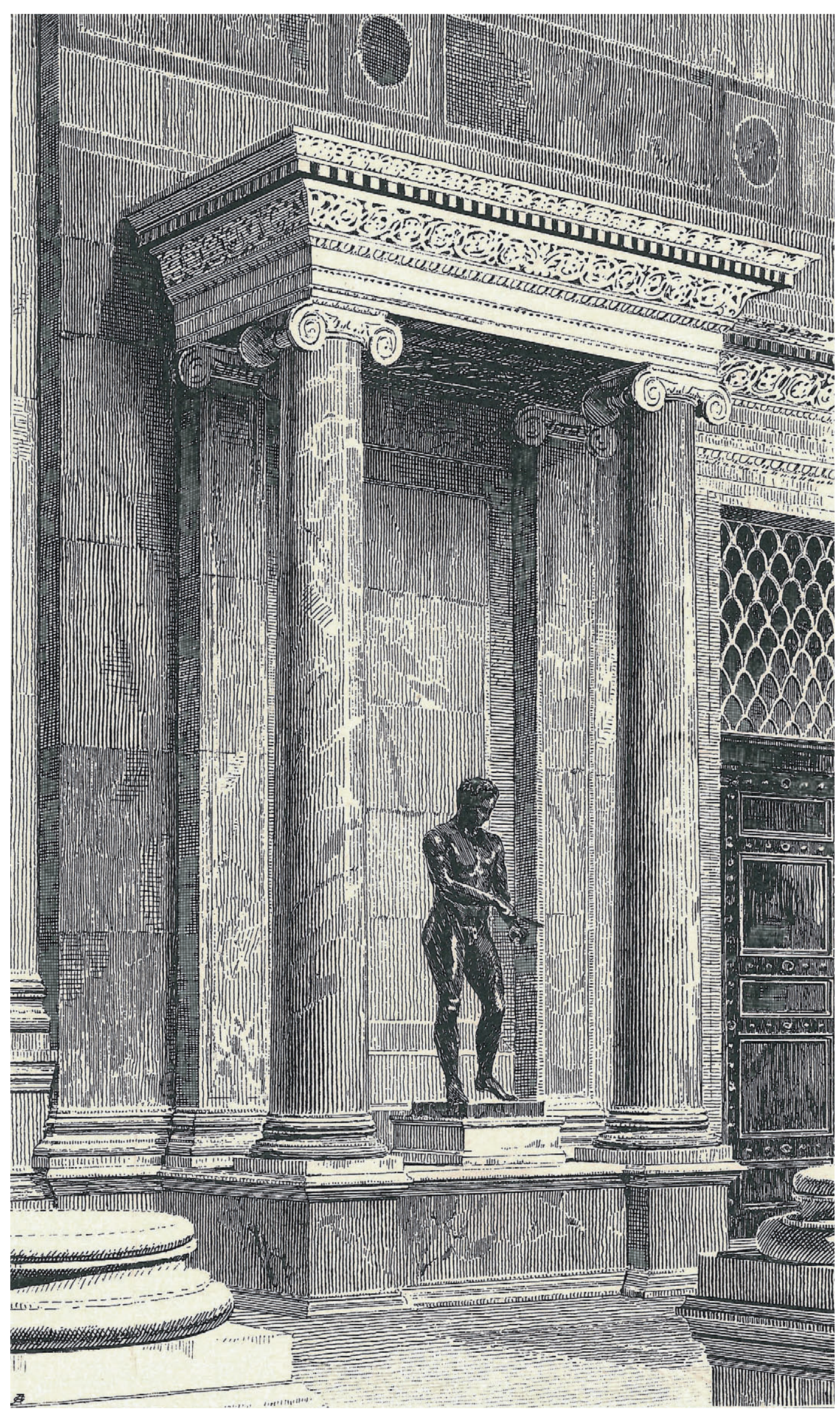

Fig. 11. Reconstruction of original position of the Athlete. () After Benndorf 1906, p. 185 fig. 131 
Arnold thinks of the second generation after Polykleitos (370-365 B.C.), naming - again - Daidalos from Sikyon as a possible artist ${ }^{39}$. Werner Fuchs explains the type as part of the Argive-Sikyonian tradition influenced by Lysippos (340/30 B.C.). A. F. Stewart and Steven Lattimore think of a possible date of origin in the 3rd century B.C., among the followers of Lysippos ${ }^{40}$. Finally Erwin Pochmarski even proposes an Imperial original in Rome (in an eclectizing manner?) from which a direct copy was taken ${ }^{41}$.

\section{The athlete from Lošinj}

The discovery of the "twin" of the Ephesian Athlete, the Apoxyomenos from Mali Lošinj ${ }^{42}$, in 1996, turned the attention again also to the Ephesian Athlete ${ }^{43}$. For the first time, it is possible to compare two bronze statues of the same type found in completely different circumstances and even different regions of the Mediterranean. It also proves, finally, the correct reconstruction of the Ephesian Athlete. The technical aspects of both statues seem to be quite similar, which leads to the assumption that both statues are Roman Imperial, probably from the same decades. The mounting of the head is, for example, consistent in both sculptures with the characteristic V-shaped lower edge of the neck.

The overall impression, though, differs: the Ephesian athlete seems to be slightly more muscular. Of course, fixing 234 fragments together causes as many joints, perhaps "inflating" the chest to a certain degree. However, this is not enough to explain the differences.

It became possible to compare the sculptures standing next to each other during the exhibition Power and Pathos, organized by the Getty Museum in 2015, discussing and understanding issues of technique and style ${ }^{44}$.

\section{Investigations and prospects}

Last but not least, the necessity to transport the statue - and the risks involved - motivated a new and intensive investigation of the Ephesian Athlete. In the last years, the staff of the Collection of Greek and Roman Antiquities at the Kunsthistorisches Museum was concerned about the condition of the 100 year-old restoration and initiated a series of studies and thorough documentation of the surface of the bronze ${ }^{45}$. On the occasion of the exhibition "Die Griechische Klassik" in the Martin-Gropius-Bau, the Ephesian Athlete was taken to Berlin in 2002. Before its installation in the exhibition, the sculpture was brought to the Bundesanstalt für Materialforschung und -prüfung (BAM) where a series of $\mathrm{x}$-ray photographs were taken (fig. 12). The images clearly show the iron bars from the first conservation work as well as the brass strings and the screws to fix the single fragments of ancient bronze to the "skeleton".

Since 2012, several investigations, of a more limited scale, tried to evaluate the damage that old restoration materials (iron, hygroscopic cement) might have caused. A further series of x-ray images done by the TÜV Austria (Technischer Überwachungsverein) and chemical analyses of the cement ${ }^{46}$ show the surprisingly high quality and stability of Sturm's reconstruction, more than hundred years after its assembling.

So, the focus of investigation was brought back to the ancient techniques of bronze casting and mounting the single elements as well as to art historical discussion. The possibility to see both Apoxyomenoi from Ephesos and Croatia side by side provided a new impact in understanding the style and iconography of these most famous sculptures. The focus of an ongoing research project in cooperation with the Getty Museum will be a review of the dating of the Greek original as well as of the Roman copies; furthermore it involves a comprehensive discussion of the "mechanisms of original and copy" in ancient Greek and Roman sculpture.

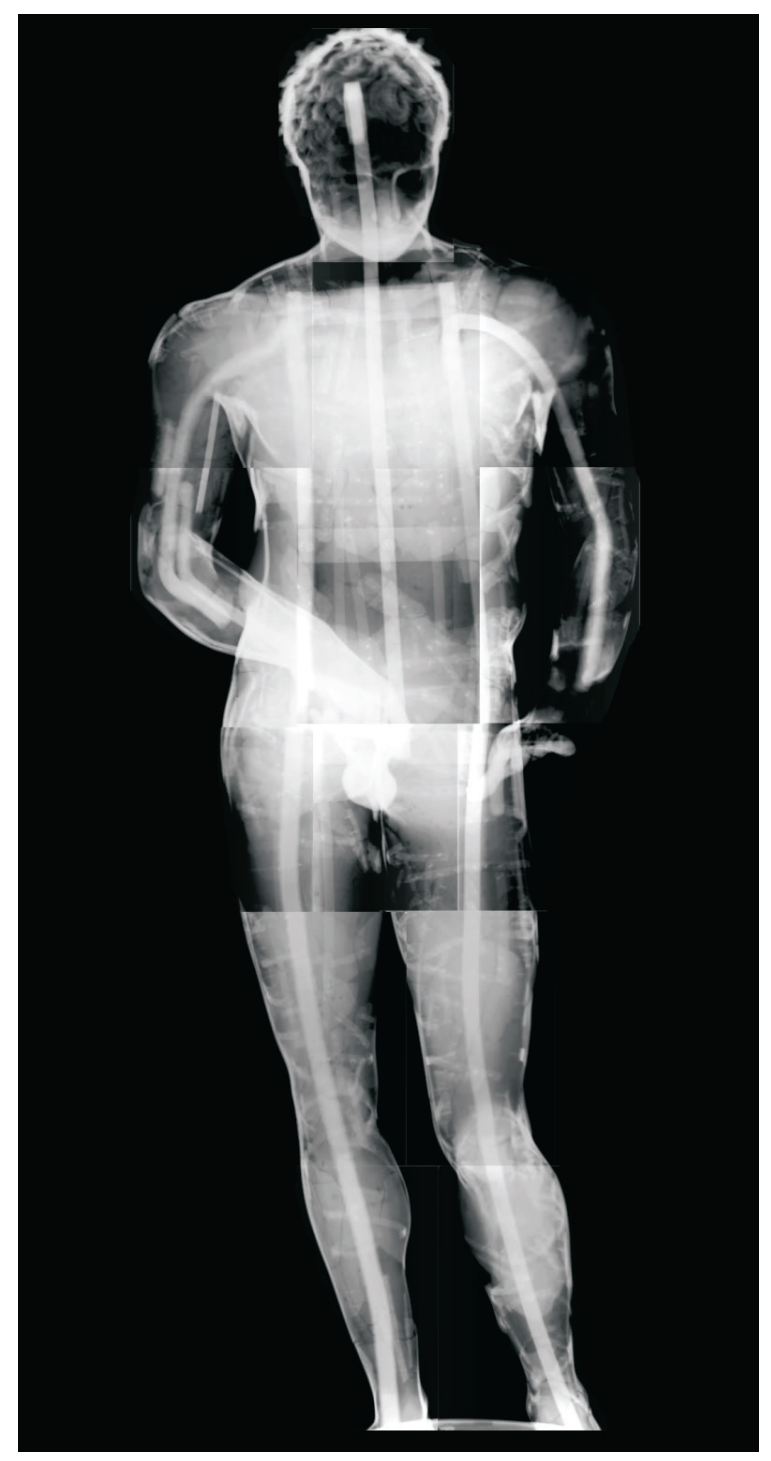

Fig. 12. X-ray-research at the Bundesanstalt für Materialforschung und -prüfung (BAM) Berlin in 2002. (C) Kunsthistorisches Museum Vienna. 


\section{Notes}

1. Benndorf, 1906, p. 181-184; WohlersScharf, 1995, p. 79-83.

2. Benndorf, 1898 , p. $64-69$. 1906.

3. Benndorf, 1898, p. 66-67; Benndorf,

4. Wohlers-Scharf, 1995 , p. $87-88$ and 98-99; Oberleitner, 1978, p. 36; among precious gifts sent in return, the Sultan received Lippizaner horses.

5. Oberleitner, 1978, p. 7-10.

6 . The annual report of the Collection of Greek and Roman Antiquities, former k.k. Münz- und Antikenkabinett, from 1897 contains a short report: "Die bedeutendste Schenkung an die Antikensammlung sind die von S.M. dem Sultan gewidmeten Ausgrabungen von Ephesus, welche die österreichische Expedition dort ergraben und nach Wien gebracht hat, darunter Teile einer überlebensgroßen bronzenen Athletenstatue, ein bronzenes Thymiaterion, Bruchstücke einer Bronzgruppe des Hercules mit den Kentauren, Säulenschäfte aus kostbarem Marmor, einige Skulpturen und eine große Menge von Fragmenten. Dieser Schenkung solle hier aus dem Grund gedacht werden, weil sie zu Beginn des Jahres 1897 nach Wien gelangt und die allerhöchste Annahme in diesem Jahr erfolgt ist. Die Zusammensetzung der Bruchstücke ist aber unterbrochen worden teils durch Abwarten, ob die im Herbst 1897 fortgesetzten Ausgrabungen noch fehlende Fragmente bringen möchten, teils durch das verzögerte Eintreffen eines Gipsabgusses der Florentiner Athletenstatue, die als Modell für die Zusammensetzung der Bruchstücke unseres bronzenen Athleten dienen soll. Die Marmorskulpturen scheinen der römischen Kaiserzeit anzugehören, während die Epoche der Entstehung der Bronzestatue noch einen Gegenstand der Erörterung in den Fachkreisen bildet." (Zl. AS 9 from Jan. 28th 1898).

7. Benndorf, 1906, p. 186-188.

8. It appears to be a type of "SorelCement", a mortar based on magnesium chloride, which was widely used as restoration material in the beginning of the 20th century.

9. Schneider, 1901, p. 1-3.

10. Svoronos, Barth, 1908, p. 15. Moraitou G., 2017, p. 240.

11. Mansuelli, 1958, p. 59-60, Cat. No. 36.

12. The cast is still kept in the collection of the Institute of Classical Archaeology, Vienna University; Pavese, 1999, compares accurately different dimensions and proportions of the Viennese and Florentine statue, the result - extensive analogy - comes not as a surprise knowing that Sturm used this copy.

13. For the first years of exhibition in the Theseus temple, a Roman strigilis kept in the Kunsthistorisches Museum was mounted into the right hand of the Athlete to clarify the movement for the visitors, cf. fig. 6 .

14. Hartwig, 1901; Benndorf, 1906 , p. 195-197; Comstock, Vermeule, 1976 , p. 100-101, Cat. No. 155.

15. The Viennese reconstruction was already questioned by Hauser, 1902.
16. Benndorf, 1906, p. 195-197.

17. Eichler, 1953.

18. Benndorf, 1906, p. 185, fig. 131.

19. Heberdey, 1919, p. 250: "Der rechte Fuß lag etwa zwei bis drei Schritte Nordost vom Ädikulasockel entfernt, an ihn schlossen sich in gleicher Richtung und ungestörter Folge die übrigen Bruchstücke bis zu dem durch glückliche Verkeilung einiger großer Gebälkstücke und eine bei dem Fall entstandene Mulde im Fußboden vor stärkerem Schaden bewahrten Kopfe."

20. Benndorf, 1898, p. 65-66; Benndorf, 1906, p. 184.

21. Pülz, 2010, p. 552-554.

22. Wood, 1877 , p. $34-35$.

23. Kunsthistorisches Museum, Inv. No. III 1087; Engelmann - Knibbe -

Merckelbach, 1980, p. 89 No. 1128.

24. Engelmann - Knibbe - Merckelbach 1980 , p. 89-90 No. 1129. 1129a-c; Benndorf, 1898 , p. $65-66$.

25. Heberdey, 1919

26. Willer, 1996.

27. Willer, 1996, p. 362-370.

28. Ladstätter, 2002, p. 23-26.

29. George Niemann, architect and draftsman of the Austrian mission, reconstructed the aedicula from the few remaining parts.

30. Statues of the type Florence/ Ephesos/Mali Lošinj:

1. Ephesos (Vienna, Kunsthistorisches Museum/Ephesos Museum, Inv. No. VI 3168)

2. Florence (Florence, Galleria degl Uffizi Inv. No. 1914/100; existing already under Cosimo I, in the Gallery since 1740; Mansuelli 1958, p. 59-60 Cat. No. 36)

3. Mali Lošinj (Mali Lošinj, Muzej Apoksiomena; Michelucci 2006)

4. Frascati (Boston, Museum of Fine Arts, Inv. No. 00.304; small scale; Comstock, Vermeule 1976, p. 100-101 No. 155)

5. Tivoli (Musei Vaticani Nr. 105, Braccio Nuovo, torso; Neudecker 1988 , p. 236 No. 68,3 pl. 15,3 )

6. Rome (Musei Vaticani, Mus. Chiaramonti Braccio Nuovo 99, Torso with head type Torino/Braccio Nuovo; Arnold 1969, p. 270 No. K7; Neudecker 1988, p. 236 No. 68,4 pl. 15,2$)$

7. Castel Gandolfo (Villa Barberini/ Castel Gandolfo No. 36405, Basalt; Liverani 1989, p. 59, No. 22)

8. Louvre (Musee du Louvre, Statue Borghese; Benndorf 1906, p. 200-201 fig. 153 ; Arnold 1969, p. 270, No. K8)

31. Heads of the type Florence/ Ephesos/Mali Lošinj:

1. Kimbell Art Museum, Fort Worth (since 2000, before Senator Bernardo Nani [1712-1761], Venice. Lucien Guiraud [Hotel Drouot, Paris], sale June 14 and 15, 1956, no. 106 (as 16th century); Hans Calmann [18991982], London and Somerset; auction, Sotheby's, New York, June 14, 2000, No. 60; Daehner-Lapatin, 2015, p. 276-277)

2. Eremitage Petersburg (Benndorf, 1906, p. 199, fig. 150-151; Arnold, 1969, p. 269-207 No. K2)

3. Museo Torlonia Rom (Götze, 1938, p. 226; Arnold, 1969, p. 270 No. K4; Gasparri, 1980, p. 166 No. 86)

4. Head of statue in Musei Vaticani
(Amelung, 1903, p. 114, No. 99)

5. New York (head of statue; Richter 1954, p. 110)

6. Bruxelles, Musée Royaux d'Art et d'Histoire (Cumon,t 1913, p. 10 fig. $5=$ Hartwig 1901, p. 158 fig. 185)

The Head Dresden No. 132 is no longer thought to follow the same type as Dörig 1965, p. 40 proposed; see now Vorster 2011.

32. Small scale Bronze statuettes:

1. Trier (Furtwängler, 1989, p. 9-11,

fig. 5; Benndorf, 1906, p. 201, fig. 154)

2. Louvre (Br 4240, Charbonneaux 1941, p. 42 fig. 1; Arnold 1969, p. 166-167 pl. 21b)

33. Vienna, Kunsthistorisches Museum, inv. no. V 1895, cf. Hartwig 1903; for the type see Perry 1997, p. 42-45 with further examples; a Campana relief from the same type is also on display in the Louvre, inv. no. CA 1500 .

34. Furtwängler, 1893, p. 470-471 fig. 78 ; Benndorf, 1906 , p. 198-199, fig. 148 149 . $401 \mathrm{a}$

35. Walter, 1923, p. 195-198, No. 401-

36. Hauser, 1902

37. Benndorf, 1906, p. 204.

38. Moser von Filseck, 1988, p. 111-120.

39. Arnold, 1969 , p. 155-156. 269, No. 1; also Linfert 1990 includes the Ephesian Athlete in the group of Polykleitos' school.

40. Lattimore, 1972; Stewart, 1978.

41. Pochmarski, 1988; Pochmarski, 1999; as a proof he mentions the unevenness of the surface of the Ephesian Athlete going back to tasselli, repair patches of the statue copied in Rome; however, due to the condition of the fragments when they were found and to the massive physical treatment they underwent when being restored, this observation does not convince.

42. Sanader, 1999; Michelucci, 2006.

43. As in the strict sense of the word, the athletes are not scraping themselves but rather are cleaning their scrapers, they are no more Apoxyomenoi but strigilis-cleaners, cf. Weber, 1999.

44. The Exhibition "Power and Pathos" curated by Jens Daehner and Kenneth Lapatin from the J. Paul Getty Museum had venues in Florence, Los Angeles and Washington, see Exhib. FlorenceLos Angeles-Washington, 2015.

45. Kurt Gschwantler, Viktor Freyberger and Frank Willer made investigations, see Gschwantler 1995; over the last two years, Angelika Kathrein, Michael Loacker and Bettina Vak have been involved in the project together with the author.

46. The samples were taken and analysed by Jerry Podany and John Twilley, The Getty, and Martina Griesser and Václav Pitthard, Conservation Science Department of the Kunsthistorisches Museum Vienna. 


\section{Bibliography}

Amelung W., 1903, Die Sculpturen des vaticanischen Museums I, Kommission bei Georg Reimer, Berlin.

Arnold D., 1969, Die Polykletnachfolge: Untersuchungen zur Kunst von Argos und Sikyon zwischen Polyklet und Lysipp. Jahrbuch des Deutschen Archäologischen Instituts, Ergänzungsheft 25, de Gruyter, Berlin.

Benndorf O., 1898, "Vorläufiger Bericht über die Ausgrabung in Ephesus I", Jahreshefte des Osterreichischen Archäologischen Instituts 1 Beibl., p. 53-72.

Benndorf O., 1906, "Erzstatue eines griechischen Athleten", in Forschungen in Ephesos, edited by O. Benndorf et al., p. 181-204. Forschungen in Ephesos I, Hölder, Vienna.

Charbonneaux, J. 1941, "Statuette d'athlète au musée du Louvre”, Monuments et mémoires. Fondation E. Piot 38, p. 40-54.

Comstock M. B., Vermeule C. C, 1976, Sculpture in Stone: the Greek, Roman, and Etruscan collections of the Museum of Fine Arts, Boston, Museum of Fine Arts, Boston.

Cumont F., 1913, Musées Royaux du Cinquantenaire. Catalogue des sculptures $\mathcal{E}$ inscriptions antiques (monuments lapidaires) des Musées Royaux du Cinquantenaire, Vromant, Bruxelles.

Dörig J., 1965, "Ein Jugendwerk Lysipps", Antike Plastik 4, p. 37-42.

Eichler F., 1953, "Die Bronzestatue aus Ephesos in verbesserter Wiederherstellung", Jahrbuch der Kunsthistorischen Sammlungen in Wien 50, p. 15-22.

Engelmann H., Knibbe D., Merckelbach R., 1980, Inschriften von Ephesos IV. Inschriften griechischer Städte aus Kleinasien 14, Habelt, Bonn.

Exhib. Florence-Los Angeles-Washington, 2015: Power and Pathos. Bronze Sculpture of the Hellenistic World [Exhibition, Florence, Palazzo Strozzi, 14 March-21 June 2015 ; Los Angeles, J. Paul Getty Museum, 28 July-1 November 2015 ; Washington D.C., National Gallery of Art, 6 December 2015-20 March 2016, Daehner J. M., Lapatin K. (eds.)], Giunti Editore, Fondazione Palazzo Strozzi, J. Paul Getty Trust.

Furtwängler A., 1893, Meisterwerke der griechischen Plastik, Giesecke \& Devrient, Leipzig and Berlin.

Furtwängler A., 1898, "Römische Bronzen aus Deutschland", Bonner Jahrbücher 103 , p. 1-11.

Gasparri C., 1980, "Materiali per servire allo studio del Museo Torlonia di scultura antica", Atti dell'Accademia nazionale dei Lincei, Classe di scienz e morali, storiche e filologiche. Memorie ${ }^{\circ}$ 8, 24, p. 33-238.

Götze H., 1938, "Die attischen Dreifigurenreliefs", Mitteilungen des Deutschen Archäologischen Instituts, Römische Abteilung 53, p. 189-280.

Gschwantler K., 1995, "Der Athlet von Ephesos. Ein Projekt zur Restaurierung und Konservierung der Bronzestatue",
Jahrbuch der Kunsthistorischen Sammlungen in Wien 91, p. 287-294.

Hartwig P., 1901, "Statuette eines Athleten im Museum in Boston", Jahreshefte des Österreichischen Archäologischen Instituts 4, p. 151-159.

Hartwig P., 1903, "Ein Terracottafries des Octavius mit Athletenstatuen", Jahreshefte des Österreichischen Archäologischen Instituts 6, p. 16-31

Hauser F., 1902, "Eine Vermutung über die Bronzestatue aus Ephesos", Jahreshefte des Österreichischen Archäologischen Instituts 5, p. 214-216.

Heberdey R., 1919, "Zur ephesischen Athletenbronze", Jahreshefte des Österreichischen Archäologischen Instituts 19/20, p. 247-252.

Ladstätter S., 2002, "Die Chronologie des Hanghauses 2", in F. Krinzinger (ed.), Das Hanghaus 2 von Ephesos. Studien zu Baugeschichte und Chronologie, ÖAW, Vienna, p. 9-40.

Lattimore S., 1972, "The Bronze Apoxyomenos from Ephesos", American Journal of Archaeology 76, p. 13-16.

Linfert A., 1990, "Die Schule des Polyklet", in H. Beck, P. C. Bol and M. Bückling (eds.), Polyklet. Der Bildhauer der griechischen Klassik, Frankfurt am Main 17.10.1990-20.1.1991, von Zabern, Mainz am Rhein, p. 278-281.

Liverani P., 1989, L’Antiquarium di Villa Barberini a Castel Gandolfo. Città del Vaticano.

Mansuelli G. A., 1958, Galleria degli Uffizi. Le sculture 1, Ist. Poligrafico dello Stato, Libr. dello Stato, Rome.

Michelucci M., 2006, Apoxyomenos. The Athlete of Croatia, Giunti, Florence and Milano.

Moraitou G., 2017, “The 'Odyssey' of the Conservation and Physicochemical Research of Antiquities at the National Archaeological Museum", in Lagogianni-Georgakarakos M. (ed.), Odysseys, exhib. cat. Athens, National Archaeological Museum, The Archaeological Receipts Fund, Athens, p. 237-260.

Moser von Filseck K., 1988, Der Apoxyomenos des Lysipp und das Phänomen von Zeit und Raum in der Plastik des 5. und 4. Jhs. v. Chr., Habelt, Bonn.

Neudecker R., 1988, Die SkulpturenAusstattung römischer Villen in Italien, von Zabern, Mainz am Rhein.

Oberleitner W., Gschwantler K., BernhardWalcher A., Bammer A., 1978, Funde aus Ephesos und Samothrake. Kunsthistorisches Museum, Katalog der Antikensammlung 2, Kunsthistorisches Museum, Vienna.

Pavese C. O., 1999, "L’Atleta di Ephesos", in Friesinger H. and Krinzinger F. (eds.), 100 Jahre Österreichische Forschungen in Ephesos, ÖAW, Vienna, p. 579-584.

Perry R., 1997, Die Campanareliefs. Katalog der Sammlung Antiker Kleinkunst des Archäologischen Instituts der Universität Heidelberg 4, von Zabern, Mainz am Rhein.

Pochmarski E., 1988, "Zur kunstgeschichtlichen Stellung des Schabers von Ephesos", in K. Gschwantler and A. Bernhard-Walcher (eds.), Griechische und römische Statuetten und Grossbronzen. Akten der 9. Internationalen Tagung über Antike Bronzen, Wien 21.-25. April 1986, Kunsthistorisches Museum, Vienna, p. 74-81.

Pochmarski E., 1999, "Neues zum Schaber von Ephesos", in Friesinger H. and Krinzinger F. (eds.), 100 Jahre Österreichische Forschungen in Ephesos, ÖAW, Vienna, p. 585-592.

Pülz A., 2010, "Zum Stadtbild von Ephesos in byzantinischer Zeit”, in F. Daim and J. Drauschke (eds.), Byzanz-das Römerreich im Mittelalter: Pracht und Alltag eines Weltreiches, Monographien des RGZM 84/2/2, RGZM, Mainz am Rhein, p. 541-571.

Richter G. M. A., 1954, Catalogue of Greek Sculptures in the Metropolitan Museum of Art, New York, Havard University Press, Cambridge/Massachusetts.

Sanader M., 1999, "Der Meergeborene. Die Entdeckung einer Bronzestatue in Kroatien”, Antike Welt 30/4, p. 357-359.

Schneider R. V., 1901, Ausstellung von Fundstücken aus Ephesos im Griechischen Tempel im Volksgarten, Holzhausen, Vienna.

Stewart A. F., 1978, "Lysippan Studies 3. Not by Daidalos?", American Journal of Archaeology 82, p. 473-482.

Svoronos J. N., Barth W., 1908, Das Athener Nationalmuseum, Beck \& Barth, Athens

Vorster Ch., 2011, "Kopf des Herakles, Typus Landsdowne-Genzano”, in: K. Knoll, Ch. Vorster, and M. Woelk (eds.), Skulpturensammlung Staatliche Kunstsammlungen Dresden. Katalog der antiken Bildwerke II. Idealskulptur der römischen Kaiserzeit 2, Hirmer, München, p. 652-655.

Walter O., 1923, Beschreibung der Reliefs im Kleinen Akropolismuseum in Athen, Hölzel, Vienna.

Weber M., 1996, “Zum griechischen Athletenbild. Zum Typus und zur Gattung des Originals der Apoxyomenosstatue im Vatikan", Mitteilungen des Deutschen Archäologischen Instituts, Römische Abteilung 103, p. 31-49.

Weber M., 1999, "Zur Gattung des Strigilisreinigers", in H. Friesinger and F. Krinzinger (eds.), 100 Jahre Österreichische Forschungen in Ephesos, ÖAW, Vienna, p. 593-596.

Willer F., 1996, "Beobachtungen zur Sockelung von bronzenen Statuen und Statuetten", Bonner Jahrbücher 196, p. 337-370.

Wohlers-Scharf T., 1995, Die Forschungsgeschichte von Ephesos: Entdeckungen, Grabungen und Persönlichkeiten, Lang, Frankfurt am Main and Vienna.

Wood J. T., 1877, Discoveries at Ephesus, Longmans, Green, London. 